\title{
THE PRIMARY PROFESSION OF SOCIAL WORKER: EKSISTENSI PEKERJA SOSIAL SEBAGAI SUATU PROFESI
}

Oleh :

Rizki Bunga Lestari, Soni Akhmad Nulhaqim, Maulana Irfan

\author{
rizkibungalestari@yahoo.com
}

\begin{abstract}
:
The fundamental essence of the packaging development of social welfare through a variety of welfare services is equitable distribution of all components with human rights standards. With a base rights, quality of service has become a claim. Social services as demand human rights are very important, and a good quality of service becomes a necessity that can not be denied. Therefore, social services should be planned systematically, and meet the quality standards of service in accordance with the philosophy of the nation, and the demands of professionalism. In the circumstances of the development of social problems and public demand for policy orientation and development programs of social welfare, which is based on fairness for all and protect human rights in the future, it takes a professional staff of social work. Thus, the purpose of writing this article is to change the mindset of society, to improve the existence of social workers as a profession to the public not just a charity activity but as a profession that has the knowledge, skills, and values in practice.
\end{abstract}

Key words: existence, profession, social work

\begin{abstract}
Abstrak :
Esensi mendasar dari kemasan pembangunan kesejahteraan sosial melalui berbagai pelayanan adalah pemerataan kesejahteraan hidup seluruh komponen bangsa dengan standar hak asasi manusia. Dengan basis hak asasi, kualitas pelayanan sudah menjadi tuntutan. Pelayanan sosial sebagai tuntutan hak asasi manusia sangat penting, dan kualitas pelayanan yang baik menjadi keharusan yang tidak dapat dipungkiri. Karenanya, pelayanan sosial harus terencana secara sistematis, serta memenuhi standar kualitas pelayanan yang sesuai dengan filosofi bangsa, dan tuntutan profesionalisme. Dalam situasi dan kondisi perkembangan permasalahan sosial dan tuntutan publik terhadap orientasi kebijakan dan program pembangunan kesejahteraan sosial yang bertumpu pada keadilan untuk semua dan melindungi hak asasi manusia pada masa yang akan datang, dibutuhkan tenaga-tenaga profesional pekerjaan sosial. Maka, tujuan penulisan artikel ini adalah untuk mengubah mindset masyarakat, meningkatkan eksistensi pekerja sosial sebagai suatu profesi kepada khalayak bukan hanya sekedar kegiatan charity melainkan sebagai suatu profesi yang memiliki knowledge, skill, dan values dalam praktiknya.
\end{abstract}

Kata kunci: eksistensi, pekerja sosial, profesi 


\section{PENDAHULUAN}

Dalam berita website Metro TV dijelaskan bahwa kemampuan pemerintah melalui Kementerian Sosial dalam menangani masalah sosial dalam lima tahun terakhir hanya menjangkau rata-rata sekitar $8 \%$ dari total Penyandang Masalah Kesejahteraan Sosial (PMKS) yang mencapai sebanyak 15,5 juta jiwa.

Dari fakta tersebut, maka dibutuhkan suatu profesi yang sangat berperan dalam hal tersebut sebagaimana yang dijelaskan oleh Zastrow (2004) dalam Introduction to Social Work and Social Welfare, telah menggambarkan bahwa profesi utama yang paling berperan dalam pembangunan kesejahteraan sosial adalah Pekerjaan Sosial. Selain itu, Zastrow pun menjelaskan bahwa pekerjaan sosial sebagai suatu profesi memiliki fungsi dan tugas pokok untuk memberikan pelayanan dalam rangka mencapai keberfungsian sosial orang melalui proses interaksi sosial.

"Pekerjaan Sosial adalah sebagai profesi terdepan dalam pemberian pelayanan sosial untuk membantu orang, baik secara individual, kelompok, keluarga, maupun masyarakat, dalam memecahkan rnasalah sosial yang dihadapinya. Tanggung jawab inilah yang menjadi misi utama Pekerja Sosial. Misi utama Pekerja Sosial bukan sekedar membantu pemecahan masalah, tetapi juga menciptakan kondisi-kondisi kemasyarakatan pokok yang menunjang pencapaian tujuan itu. Hal tersebut dibutuhkan manusia agar mampu mengarungi kehidupan secara fungsional dalam menghadapi perubahan sosial yang cepat ini." (Zastrow, 2004: 13)

Selain itu, dalam referensi tersebut dipaparkan definisi lainnya. The National Association of Social Work (NASW) mendefinisikan pekerjaan sosial sebagai kegiatan profesional membantu individu, kelompok, atau masyarakat meningkatkan atau mengembalikan kapasitas mereka untuk fungsi sosial dan menciptakan kondisi sosial yang menguntungkan untuk tujuan ini. Praktek kerja sosial terdiri dari profesional penerapan sosial nilai kerja, prinsip, dan teknik untuk satu atau lebih untuk membantu orang mendapatkan pelayanan yang nyata (misalnya, yang melibatkan penyediaan makanan, perumahan, atau pendapatan); memberikan konseling dan psikoterapi dengan individu, keluarga, dan kelompok; membantu masyarakat atau kelompok menyediakan atau meningkatkan pelayanan sosial dan kesehatan; berpartisipasi dalam proses legislatif yang relevan. (NASW, 1973, p. 4-5)

NASW melaporkan bahwa Bob Etheridge (D-N.C.) sebagai wakil rakyat memberi penghormatan kepada pekerja sosial. Ia berbagi dengan pembicara dari DPR AS dan memberikan komentar sebagai berikut:

"Para pekerja sosial mempengaruhi kehidupan kita dalam banyak cara. Pekerjaan mereka menyentuh kita semua sebagai individu dan sebagai seluruh masyarakat. Mereka berpendidikan, sangat terlatih, dan berkomitmen profesional. mereka bekerja dalam pelayanan keluarga dan kesehatan mental masyarakat instansi, sekolah, rumah sakit, panti jompo, dan banyak lembaga swasta dan publik lainnya. Mereka mendengarkan, mereka peduli. Dan yang paling penting, mereka membantu mereka yang membutuhkan." (Vallianatos, 2012)

Saat ini di Indonesia diperkirakan terdapat lebih dari 36.000 Pekerja Sosial professional lulusan dari 37 Perguruan Tinggi yang menyelenggarakan pendidikan Pekerjaan Sosial/Kesejahteraan Sosial. Sebagian besar dari jumlah Pekerja Sosial 
profesional tersebut tergabung dalam Ikatan Pekerja Sosial Profesional Indonesia (IPSPI). Banyak dari mereka bekerja di Lembaga Swadaya Masyarakat (LSM) Nasional maupun Internasional. Sebagian besar lagi bekerja di Instansi Pemerintah dan lembaga pelayanan kesejahteraan sosial baik milik pemerintah maupun masyarakat (swasta). Berdasarkan data populasi Pekerja Sosial tersebut, diketahui pula data sampai Mei 2013 jumlah Pekerja Sosial fungsional sebanyak 1.154 orang yang bekerja di instansi pemerintah pusat dan daerah. (http://www.microsite.metrotvnews.com/metr onews/read/2014/09/02/3/185591/ diakses pada 1 Oktober 2014 pukul 14.07 WIB)

Dalam situasi dan kondisi perkembangan permasalahan sosial dan tuntutan publik terhadap orientasi kebijakan dan program pembangunan kesejahteraan sosial yang bertumpu pada keadilan untuk semua dan melindungi hak asasi manusia pada masa yang akan datang, dibutuhkan tenaga-tenaga profesional pekerjaan sosial. Jika ratio Pekerja Sosial (Social Worker) dengan penyandang masalah kesejahteraan sosial minimal satu berbanding 100, maka kebutuhan Pekerja Sosial di Indonesia paling sedikit sebanyak 155.000 orang. Estimasi jumlah PMKS tahun 2014 sebanyak 15,5 juta keluarga, sedangkan jumlah Pekerja Sosial saat ini sekitar 15.522 orang. Dengan demikian masih diperlukan sekitar 139.000 Pekerja Sosial.

Kebutuhan akan pekerja sosial yang terus meningkat untuk menangani Penyandang Masalah Kesejahteraan Sosial (PMKS) yang berjumlah 15,5 juta rumah tangga tidak diimbangi dengan lulusan perguruan tinggi kesejahteraan sosial serta peminat masyarakat untuk mengikuti pendidikan pekerjaan/kesejahteraan sosial, hal ini salah satunya dikarenakan masyarakat belum mengenal pekerja sosial sebagai profesi yang profesional, masyarakat lebih mengenal pekerjaan sosial sebagai kegiatan karitas. Mereka berpandangan bahwa bidang pekerjaan ini sesungguhnya dapat dilakukan oleh siapapun, tidak harus dari lulusan pendidikan pekerjaan sosial. Hal ini pula yang kemudian dapat menyebabkan kualitas pelayanan dan penanganan masalah menjadi tidak optimal dan mencapai hasil yang diharapkan.

Hal tersebut diperjelas dalam website P4S Kemsos (2014) bahwa sebutan pekerja sosial profesional ini dimaksudkan untuk membedakan dengan mereka yang bekerja dalam bidang pekerjaan sosial tapi bukan berasal dari lulusan pendidikan pekerjaan sosial. Namun, hal ini tidak dapat dihindari karena dalam kenyataannya banyak bidang pekerjaan sosial yang digarap oleh mereka yang bukan berasal dari lulusan pendidikan pekerjaan sosial. Lahan yang seharusnya digarap oleh profesi pekerjaan sosial akan diambil alih oleh profesi lain.

Lahan yang dimaksud adalah ranah pekerjaan yang membutuhkan keahlian spesifik dan hanya dapat dilakukan oleh pekerja sosial. Banyak bidang pekerjaan peksos yang saat ini masih menjadi garapan profesi lain, seperti psikolog, keperawatan dan profesi lainnya. Pekerja sosial memang profesi yang menggunakan hati, tapi RUU akan memperkuat posisi pekerja sosial profesional dan bermanfaat sebagai bentuk pertanggungjawaban praktik pekerjaan sosial kepada masyarakat luas. Dalam beberapa kasus bahkan kita menemukan adanya pegiat dalam bidang pekerjaan sosial yang bukan berasal dari pendidikan pekerjaan sosial yang berhasil menyelenggarakan kegiatan pelayanan sosial lebih baik. Kedua kondisi 
tersebut semakin memperlemah eksistensi pekerjaan sosial sebagai bidang keahlian yang spesifik.

Ditambah lagi saat ini jabatan peksos bisa diisi oleh semua jurusan untuk masuk CPNS di beberapa provinsi. Berdasarkan hemat saya, hal ini terjadi antara lain karena tidak adanya regulasi yang mengatur bahwa bidang pekerjaan yang sesungguhnya secara spesifik hanya dapat dilakukan oleh pekerja sosial tidak dapat diserahkan kepada oleh mereka yang bukan pekerja sosial.

Berdasarkan situs resmi KemenPAN$\mathrm{RB}$, adapun 11 jabatan yang dapat dilamar oleh sarjana dari semua jurusan masingmasing instansi adalah, Analis Kebijakan, Perencana, Auditor, Pengawas Penyelenggara Urusan Pemerintahan daerah, Penggerak Swadaya Masyarakat, idyaiswara, Peneliti, Pekerja sosial, Penyuluh sosial, Perekayasa, dan Pemeriksa."Bagi instansi pemerintah yang belum mengalokasikan formasi untuk 11 jabatan yang bisa dilamar oleh saraja dari semua jurusan tersebut supaya segera mengalokasikannya," kata Kepala Biro Hukum, Komunikasi dan Informasi Publik Kementerian PANRB Herman Suryatman.

Namun sayangnya, sampai sekarang banyak instansi pemerintah pusat maupun daerah yang belum mengalokasikan untuk jabatan 5\% yang dapat dilamar oleh sarjana dari semua jurusan. Kepala Badan Kepegawaian Daerah (BKD) Provinsi Bengkulu, Tarmizi, B.Sc, S.Sos saat dikonfirmasi mengatakan tidak semua jabatan tersebut akan diisi. Hanya dua jabatan yang memungkinkan, yakni Pekerja sosial dan Penyuluh sosial. "Kalau untuk jabatan lain sudah banyak, seperti auditor. Dan kedua jabatan itu (Pekerja sosial dan Penyuluh sosial), juga tidak begitu spesifik," kata Tarmizi. (http://harianrakyatbengkulu.com/ver3/2014/0 7/25/11-jabatan-cpns-bisa-dilamar-sarjanasemua-jurusan/\#)

Banyak pilar penting yang telah dibangun untuk mengembangkan praktik Pekerjaan Sosial di Indonesia. Sudah ada UU yang menuntut profesi Pekerjaan Sosial untuk melaksanakan praktik, seperti (a) UU No 11 Tahun 2012 tentang system peradilan Pidana Anak yang mengamanatkan pendampingan Pekerja Sosial bagi anak-anak yang berkonflik dengan hukum, (b) UU tentang Sisdiknas atau peraturan turunannya yang mengharapkan adanya praktik Pekerjaan Sosial di sekolah, (c) UU No 4 Tahun 1997 tentang Penyandang Cacat, (d) UU No 5 Tahun 1997 tentang psikotropika; UU No 13 Tahun 2011 tentang penanganan fakir miskin. Undang-undang No 11 tahun 2009 tentang Kesejahteraan Sosial, menjadi panduan utama dalam penciptaan kerangka sistem kesejahteraan sosial di Indonesia.

UU ini menyebutkan pekerja sosial sebagai "the primary profession" dalam penyelenggaraan kesejahteraan sosial. Sistem kesejahteraan sosial, sebagaimana terkandung dalam UU No 11 Th 2009 ini merupakan arah sistematis dalam mencapai kondisi yang akan dituju. Namun, UU ini mengandung banyak kelemahan. Penyelenggaraan kesejahteraan sosial yang diamanatkan UU Nomor 11 Tahun 2009 tentang Kesejahteraan Sosial belum mengatur standar Praktik Pekerjaan Sosial di Indonesia.

Adanya kebutuhan terhadap standar registrasi, akreditasi, dan sertifikasi. Lembaga Sertifikasi Pekerja Sosial Indonesia (LSPSI) serta Badan Akreditasi Lembaga Kesejahteraan Sosial (BALKS) sebagai pilar pengendali praktik pekerjaan sosial maupun lembaga pelayanan kesejahteraan sosial juga 
telah terbentuk dan dan akan terus berkembang.

Maka dari itu, untuk mewujudkannya dibutuhkan beberapa upaya yang harus dilakukan salah satunya melalui penulisan artikel ini diharapkan dapat mengubah paradigma khalayak akan pekerja sosial sebagai suatu profesi begitupun dengan lapangan praktik pekerja sosial akan lebih diakui oleh semua pihak.

\section{EKSISTENSI PEKERJA SOSIAL SEBAGAI SUATU PROFESI}

\section{Apa itu Pekerjaan Sosial dan \\ Kesejahteraan Sosial?}

Zastrow (2004) dalam Introduction to

Social Work and Social Welfare, telah menggambarkan bahwa profesi utama yang paling berperan dalam pembangunan kesejahteraan sosial adalah Pekerjaan Sosial. Selain itu, Zastrow pun menjelaskan bahwa pekerjaan sosial sebagai suatu profesi memiliki fungsi dan tugas pokok untuk memberikan pelayanan dalam rangka mencapai keberfungsian sosial orang melalui proses interaksi sosial.

"Pekerjaan Sosial adalah sebagai profesi terdepan dalam pemberian pelayanan sosial untuk membantu orang, baik secara individual, kelompok, keluarga, maupun masyarakat, dalam memecahkan rnasalah sosial yang dihadapinya. Tanggung jawab inilah yang menjadi misi utama Pekerja Sosial. Misi utama Pekerja Sosial bukan sekedar membantu pemecahan masalah, tetapi juga menciptakan kondisi-kondisi kemasyarakatan pokok yang menunjang pencapaian tujuan itu. Hal tersebut dibutuhkan manusia agar mampu mengarungi kehidupan secara fungsional dalam menghadapi perubahan sosial yang cepat ini." (Zastrow, 2004: 13)

Selain itu, dalam referensi tersebut dipaparkan definisi lainnya. The National Association of Social Work (NASW) mendefinisikan pekerjaan sosial sebagai kegiatan profesional membantu individu, kelompok, atau masyarakat meningkatkan atau mengembalikan kapasitas mereka untuk fungsi sosial dan menciptakan kondisi sosial yang menguntungkan untuk tujuan ini. Praktek kerja sosial terdiri dari profesional penerapan sosial nilai kerja, prinsip, dan teknik untuk satu atau lebih untuk membantu orang mendapatkan pelayanan yang nyata (misalnya, yang melibatkan penyediaan makanan, perumahan, atau pendapatan); memberikan konseling dan psikoterapi dengan individu, keluarga, dan kelompok; membantu masyarakat atau kelompok menyediakan atau meningkatkan pelayanan sosial dan kesehatan; berpartisipasi dalam proses legislatif yang relevan (NASW, 1973, p. 4-5).

Di samping itu, kesejahteraan sosial adalah sistem program suatu negara, manfaat, dan layanan yang membantu orang, ekonomi, pendidikan, dan kebutuhan kesehatan yang mendasar untuk pemeliharaan masyarakat. Reid (1995) menggambarkan kesejahteraan sosial sebagai "ide, bahwa ide menjadi salah satu dari masyarakat yang layak yang menyediakan kesempatan untuk bekerja, memberikan keamanan yang wajar dari keinginan dan penyerangan, mengutamakan kejujuran dan evaluasi berdasarkan pada jasa individu, dan ekonomi produktif dan stabilitas". (hal. 206).

Lalu, bagaimana kesejahteraan sosial dan pekerjaan sosial terkait? Sederhananya, pekerjaan sosial berfungsi untuk meningkatkan ekonomi dan

kesejahteraan sosial masyarakat. Fokus pekerja sosial bukan satu-satunya dalam bidang kesejahteraan sosial masyarakat saja. Namun, hal ini berarti mencakup kesehatan, pendidikan, rekreasi, jasa, dan keamanan masyarakat.

\section{Keberlanjutan Karir Pekerjaan Sosial}

Ada berbagai cara untuk melihat kemajuan melalui karir pekerjaan sosial. Beberapa kemajuan pekerja sosial melalui serangkaian tingkatan.. Derajat dalam 
pekerjaan sosial meliputi sarjana muda, master, dan doktor. Pekerjaan sosial adalah kegiatan profesional untuk membantu individu, kelompok, atau masyarakat meningkatkan atau memulihkan kemampuan mereka untuk berfungsi sosial dan menciptakan kondisi sosial yang menguntungkan untuk tujuan ini. Kesejahteraan sosial adalah sistem suatu negara program, manfaat, dan layanan yang membantu orang bertemu orang-orang sosial, ekonomi, kebutuhan pendidikan, dan kesehatan yang penting untuk pemeliharaan masyarakat.

\section{Bidang praktik pekerjaan sosial}

Bidang praktek dalam pekerjaan sosial termasuk anak-anak dan keluarga, lansia, disabilitas, kesehatan, kesehatan mental, penyalahgunaan zat, sekolah, dan koreksional. Konteks lain untuk praktek pekerjaan sosial adalah

pekerjaan sosial pedesaan, polisi pekerjaan sosial, dan forensik pekerjaan sosial.

\section{Pekerjaan Sosial dan Disiplin Lainnya}

Dasar dari pekerjaan sosial profesional adalah pengetahuan, keterampilan, dan nilainilai. Pengetahuan tidak hanya dari pekerja sosial tetapi juga dari berbagai disiplin ilmu yang berfokus pada pemahaman kebutuhan dan perilaku masyarakat. Hal ini termasuk psikologi, sosiologi, ilmu politik, ekonomi, biologi, psikiatri, konseling, dan antropologi budaya.

Para pekerja sosial menggunakan pengetahuan yang diambil dari masingmasing bidang, dalam hubungannyadengan keterampilan kerja sosial dan nilai-nilai, untuk membantu individu, keluarga, kelompok, organisasi, dan masyarakat memecahkan masalah dan meningkatkan kualitas hidup mereka.

\section{Keunikan Pekerjaan Sosial}

Bidang lainnya melakukan beberapa fungsi yang sama sebagai pekerjaan sosial. Misalnya, kesehatan mental dokter di bidang psikologi, psikiatri, dan konseling menggunakan keterampilan wawancara, dan beberapa juga menggunakan sebuah rencana pendekatan.

Semuanya, memiliki kesamaan inti dari wawancara dan konseling keterampilan. Namun, pekerjaan sosial melibatkan lebih dari hanya duduk dengan individu, kelompok, atau keluarga dan memecahkan beberapa masalah. Pekerjaan Sosial

memiliki setidaknya lima dimensi utama yang membuatnya unik. Pertama, pekerja sosial dapat fokus pada masalah atau kelompok masalah yang kompleks dan sulit. pekerja sosial tidak menolak untuk bekerja dengan klien atau merujuk mereka ke tempat lain karena klien-klien memiliki karakteristik. Misalnya, mungkin ada sebuah keluarga di mana pelecehan seksual terjadi, dan penyalahgunaan yang harus dihentikan. Demikian juga, mungkin ada komunitas di mana tingkat kejahatan remaja adalah merajalela, dan sesuatu harus dilakukan. Tidak setiap masalah dapat diselesaikan, tetapi beberapa dapat menjadi-atau setidaknya diringankan. Praktisi kerja sosial dilengkapi dengan repertoar keterampilan untuk membantu mereka mengidentifikasi dan memeriksa masalah. Mereka kemudian membuat pilihan tentang di mana usaha mereka bisa menjadi yang terbaik untuk diarahkan.

Dimensi kedua yang membuat pekerjaan sosial yang unik adalah bahwa hal itu sering menargetkan lingkungan meliputi klien, dan bukan klien sendiri untuk perubahannya. Kadang-kadang

layanan tidak tersedia atau sulit untuk mendapatkan, kebijakan yang tidak adil, atau orang-orang ditindas oleh orang lain. administrator

dan orang yang berkuasa tidak selalu memiliki motivasi atau wawasan untuk memulai perubahan yang diperlukan. Pekerja sosial harus melihat di mana perubahan sangat penting di luar individu dan bekerja dengan lingkungan untuk memberlakukan perubahan tersebut. 
Dimensi ketiga yang membuat pekerjaan sosial yang unik terkait dengan penargetan lingkungan: yaitu, pekerja sosial sering merasa perlu untuk mengadvokasi klien mereka. Pembelaan melibatkan secara aktif campur tangan untuk membantu klien mendapatkan apa yang mereka butuhkan. Paling sering, intervensi ini

berfokus pada "hubungan antara klien dan 'sistem' tidak responsif "(Epstein, 1981, p. 8). Klien telah ditentukan kebutuhan, dan lembaga sosial, organisasi. Sistem tidak responsif harus ditekan untuk membuat perubahan sehingga kebutuhan bisa dipenuhi.

Dimensi keempat yang membuat pekerjaan sosial yang unik adalah penekanan pada

dan kepatuhan terhadap inti profesional nilainilai. Kode Etik NASW berfokus pada hak individu untuk membuat pilihan bebas dan memiliki kualitas hidup (NASW, 1999). Para pekerja sosial tidak memaksa cara berpikir atau bertindak orang tertentu. Sebaliknya, mereka membantu orang membuat keputusan sendiri tentang bagaimana untuk berpikir atau bertindak.

Kelima dimensi membuat pekerjaan sosial yang unik berkaitan dengan inti nilainilai pekerjaan sosial yakni betapa pentingnya untuk klien dalam membuat keputusan mereka sendiri. Para pekerja sosial tidak melacak cara spesifik berpikir atau bertindak seseorang. Sebaliknya, mereka berlatih dalam suatu kemitraan dengan klien, membuat dan melaksanakan rencana bersama-sama. Kebanyakan profesi lain menekankan otoritas dan keahlian profesional, pada satu tangan, dan status bawahan klien sebagai penerima jasa.

\section{Tujuan Pendidikan, Kurikulum, dan Kompetensi Pekerjaan Sosial}

Selanjutnya, muncullah pertanyaan utama: "Bagaimana dengan identitas pekerja sosial?" Pengetahuan dan kemampuan apa yang mereka miliki? Kedua faktor berperan dalam menetapkan identitas dan merupakan pertanyaan dasar bertanya dari banyak profesi. Tentu saja, masyarakat juga ingin tahu apakah mereka layak legitimasi.

Reiner Wendt, wakil dari Ekologis Teori Sosial dalam IUC Jurnal of Social Work bertanya: Bagaimana kita menciptakan identitas pekerjaan sosial, jika dalam citra diri profesional setiap bidang pekerjaan menjelaskan dirinya sebagai bidang khusus pekerjaan sosial? Konseling, pelayanan sosial klinis, karya sosial masyarakat, semua mengklaim identitas tertentu. Apakah mereka memiliki kesamaan? Apa jenis pola dasar yang dapat menggambarkan dari pekerja sosial? Bagaimana seorang pekerja sosial melihat identitasnya sendiri?

Dr. Heiko Kleve, anggota dari DBSH menunjukkan bahwa identitas ini adalah identitas pekerjaan sosial. Keterbukaan, kerapuhan, dan ambivalensi adalah karakter pekerjaan sosial. Kita harus mengucapkan selamat tinggal kepada citra idealis. Intinya adalah bahwa kita tidak bisa memiliki identitas seragam - tetapi jika hal ini tidak mungkin, dan diskusi tidak akan berhenti, maka akan tetap sulit untuk menciptakan landasan profesionalisme untuk seorang pekerja sosial.

Salah satu cara untuk memahami pekerjaan sosial yakni dengan meninjau konten dan harapan dalam akreditasi program kurikulum pekerjaan sosial. Dewan Pendidikan Pekerjaan Sosial (CSWE) adalah organisasi akreditasi program kerja sosial di seluruh Amerika Serikat. Akreditasi adalah sebutan resmi oleh yang berwenang tubuh (dalam hal ini, CSWE) bahwa pendidikan Program memenuhi standar yang ditentukan. Hal ini biasanya diperlukan dalam berlisensi sebagai pekerja sosial. Kebijakan Pendidikan CSWE dan Standar Akreditasi (EPAS) menekankan bahwa program kerja sosial harus mencerminkan nilai-nilai tertentu seluruh kurikulum mereka. EPA menyatakan bahwa "layanan, keadilan sosial, martabat dan nilai seseorang, pentingnya hubungan manusia, integritas, kompetensi, hak asasi manusia, dan penelitian ilmiah adalah salah 
satu nilai-nilai inti pekerjaan sosial "(CSWE, 2008b, hal. 2). EPA juga menetapkan 10 daerah yang lulusan dari program pekerjaan sosial harus mempunyai kompetensi.

Kompetensi adalah "perilaku praktek terukur yang terdiri dari pengetahuan yang cukup, keterampilan, dan nilai-nilai, serta memiliki tujuan untuk berlatih secara efektif. Bagian berikut menjelaskan setiap kompetensi dan mengidentifikasi bidang dalam kurikulum tradisional pekerjaan sosial. Lima kompetensi pertama melibatkan pengetahuan, keterampilan, dan nilai-nilai yang jelas seluruh kurikulum pekerjaan sosial. Lima terakhir kompetensi berhubungan dengan bidang isi tradisional atau

kursus dalam program-sosial pekerjaan sosial penelitian, perilaku manusia dan lingkungan sosial,

kebijakan sosial kesejahteraan, serta praktek pekerjaan sosial (kompetensi

9 dan 10).

a. Kompetensi 1: Identifikasi

Sebagai pekerja Pekerja Sosial profesional harus "melayani sebagai wakil profesi, misinya, dan nilai-nilai inti" (CSWE, 2008b, hal. 3). Mereka harus memiliki pengetahuan tentang sejarah dan perkembangan pekerjaan sosial. Mereka harus melakukan sendiri dalam etika, secara profesional, memberikan pelayanan yang efektif untuk klien dan menghormati hak klien untuk menentukan nasib sendiri. Dalam prakteknya, pekerja sosial harus mengadvokasi atas nama ketika layanan klien mereka atau kebijakan peningkatan penyediaan layanan pemerintahan diperlukan. Mereka harus terus mengembangkan keterampilan mereka dan memperoleh pengetahuan baru sepanjang karier mereka untuk melayani klien. Akhirnya, mereka harus mencari bantuan dari pengawas dan konsultan bila diperlukan.

b. Kompetensi 2: Penerapan Sosial

Anda mungkin telah memperhatikan bahwa nilai-nilai pekerjaan sosial dan etika sangat penting untuk praktek pekerjaan sosial. Mereka membantu para praktisi menilai apa yang penting atau benar dalam situasi dan memberikan panduan untuk membuat keputusan dan penilaian yang baik. Pekerja sosial profesional harus menunjukkan kompetensi dalam mengenali nilai-nilai pribadi. "Prinsip-prinsip penalaran etis untuk tiba di berprinsip keputusan "(CSWE, 2008b, hal. 4). Dalam kode etik NASW disebutkan sebelumnya mengenai beberapa pedoman dasar bagi para praktisi pekerjaan sosial, seperti halnya Asosiasi Internasional Pekerja Sosial Internasional / Sekolah

Etika Pekerjaan Sosial di Pekerjaan Sosial.

c. Kompetensi 3: Penerapan Kritis

Pentingnya berpikir kritis, hal ini didefinisikan sebagai (1) pengawasan hatihati apa yang dinyatakan sebagai benar atau apa yang tampaknya menjadi benar dan ekspresi yang dihasilkan dari pendapat atau kesimpulan berdasarkan pengawasan itu, dan (2) perumusan kreatif pendapat atau kesimpulan ketika disajikan dengan pertanyaan, masalah, atau isu. Sebaliknya, berpikir kritis memerlukan menggunakan analisis kreatif pengandaian untuk menentukan sendiri apa yang benar-benar benar atau apa pilihan terbaik di antara alternatif yang ada. Hal ini juga menyangkut kemampuan untuk berkomunikasi dengan jelas dan efektif, baik secara lisan maupun tertulis.

d. Kompetensi 4: Keterlibatan

Keanekaragaman dalam Praktek

Keanekaragaman mengacu pada berbagai perbedaan karakteristik orang. Fokus dari profesi pekerjaan sosial meliputi kelompok yang dibedakan dengan "usia, kelas, warna, budaya, kecacatan, etnis, gender, identitas gender dan ekspresi, status imigrasi, ideologi politik, ras, agama, jenis kelamin, dan orientasi seksual" (CSWE, 2008b, hal. 5). Setiap kali seseorang dapat diidentifikasi sebagai milik kelompok yang berbeda dari sebagian besar orang lain dalam masyarakat.

Karena pekerja sosial memiliki berbagai macam klien, menunjukkan hampir setiap jenis kebutuhan dan masalah, mereka harus 
secara integral akrab dengan konsep keragaman manusia. Adapun mpat aspek utama. Pertama, pekerja sosial harus menghargai perbedaan dan fokus pada kekuatan. Kedua, mereka harus peka terhadap dan mengatasi setiap kesulitan dan klien pengobatan negatif mungkin menghadapi karena mereka milik beberapa kelompok yang beragam. Ketiga, mereka harus introspektif menilai sikap mereka sendiri dan berusaha untuk menghilangkan prasangka yang mungkin mereka miliki. Keempat, pekerja sosial harus melihat diri mereka sebagai peserta didik seumur hidup tentang banyak aspek keragaman manusia, khususnya karakteristik klien.

e. Kompetensi 5: Peningkatan Hak Asasi Manusia serta Keadilan Sosial dan Ekonomi

Konsep hak asasi manusia dan keadilan sosial-ekonomi terkait dengan konsep keragaman manusia. Hak asasi manusia melibatkan premis bahwa semua orang, terlepas ras, budaya, atau asal negara, berhak untuk hak-hak dasar dan pengobatan. Keadilan sosial adalah gagasan bahwa di dunia yang sempurna semua warga negara akan identik "hak, perlindungan, peluang, kewajiban, dan manfaat sosial" (Barker, 2003, hal. 405). Demikian pula, keadilan ekonomi melibatkan distribusi sumber daya secara adil dan merata. Lulusan pekerja sosial harus menunjukkan kompetensi dalam memahami konsep-konsep dan

dasar teoritis mereka; pekerja sosial harus membela

atas nama prinsip-prinsip ini dan menggabungkan

prinsip ke dalam praktek mereka (CSWE, 2008b, hal. 5).

Konsep lain yang penting dalam pekerjaan sosial adalah populasi, kelompok yang terdiri dari beberapa orang diidentifikasi karakteristiknya, beserta risikonya karena praktek pekerjaan sosial melibatkan mendapatkan sumber daya manusia dan membantu mereka memecahkan masalah, pekerja sosial sering bekerja dengan populasi yang berisiko dari deprivations tersebut. Berarti pekerja sosial membutuhkan informasi dan wawasan tentang isu-isu khusus dan kebutuhan orang-orang ini. Oleh karena itu, pekerja sosial mengharuskan kedua teoritis dan konten praktek mengenai dinamika dan

hasil diferensial, perlakuan tidak adil.

Satu nilai pekerjaan sosial sangat penting adalah "proses peningkatan pribadi pemberdayaan-,

interpersonal, atau politik kekuasaan sehingga individu dapat mengambil tindakan untuk memperbaiki situasi kehidupan mereka" (Gutierrez, 2001, hal. 210). Beberapa kelompok orang mengalami stereotip, diskriminasi, dan penindasan.

Adalah tugas pekerja sosial untuk memberdayakan klien secara umum dan anggota kelompok tertindas pada khususnya.

\section{f. Kompetensi 6: Keterlibatan dalam Penelitian \\ Mahasiswa pekerja sosial harus} menunjukkan kompetensi dalam research. Ini berarti pekerja sosial harus menggunakan pendekatan dan intervensi dalam praktek mereka

bahwa penelitian telah ditentukan efektif. Para pekerja sosial harus menggunakan "temuan penelitian untuk memperbaiki praktek, kebijakan, dan pelayanan sosial" (CSWE, 2008b, hal. 5). Para pekerja sosial mungkin juga memiliki kesempatan untuk berpartisipasi dalam praktek berdasar pada

penelitian. Penelitian yang erat ini melibatkan pekerjaan sehari-hari para praktisi berfokus pada pengumpulan data dan hasil yang terkait dengan proses praktek pekerjaan sosial (Tripodi \&

Lalayants, 2008, p. 518). Program "Penelitian Pekerjaan Sosial" menjadi urutan program dalam kurikulum mereka. Pengetahuan tentang penelitian pekerjaan sosial adalah penting karena dua alasan mendasar. Pertama, dapat membantu pekerja sosial menjadi lebih efektif dalam praktek langsung mereka dengan memilih intervensi yang telah terbukti berhasil, sehingga mendapatkan hasil 
yang lebih baik dan lebih jelas. Framing intervensi pekerjaan sosial sehingga mereka dapat dievaluasi melalui penelitian memberikan informasi tentang teknik-teknik khusus bekerja yang baik dengan

yang bermasalah. Evaluasi praktek di seluruh proses intervensi dapat membantu menentukan apakah seorang pekerja benarbenar membantu klien. Kedua, akumulasi penelitian membantu membangun lembaga untuk merencanakan intervensi yang efektif. Pengetahuan dari apa yang telah bekerja terbaik di masa lalu memberikan pedoman untuk pendekatan dan teknik yang akan digunakan di masa sekarang dan di masa depan. Menetapkan penelitian dasar untuk pengembangan program dan kebijakan yang mempengaruhi banyak orang. Pengetahuan tersebut dapat juga dapat digunakan untuk menghasilkan teori-teori baru dan ide-ide untuk lebih meningkatkan efektivitas kerja sosial praktek.

Based-practice merupakan istilah lain yang sering digunakan dalam pekerjaan sosial, yang memiliki arti mirip dengan research-information practice, yaitu praktik berbasis informasi yaitu "hati nurani, eksplisit, dan penggunaan bukti/informasi terbaik saat ini dalam pembuatan keputusan tentang perawatan klien "(Gambrill, 2000, hal. 46; Race, 2008; Rubin, 2008). Gambrill (2000) menjelaskan:

"Ini meliputi keahlian praktek integrasi individu dengan fakta eksternal terbaik yang tersedia dari sistematis penelitian serta mempertimbangkan nilai-nilai dan harapan klien. Temuan penelitian eksternal berkaitan dengan masalah yang diambil jika mereka bersedia dan berlaku untuk klien tertentu mereka. Peksos melibatkan klien sebagai peserta kolaboratif membantu hubungan yang merupakan ciri dari praktek berbasis fakta. Klien sepenuhnya diinformasikan tentang risiko dan manfaat dari layanan yang direkomendasikan serta alternatif (termasuk alternatif melakukan apa). ... . Istilah praktek evidence-based adalah lebih baik untuk praktek jangka empiris. Istilah yang terakhir sekarang tampaknya diterapkan dalam materi. (pp. 46-47)

Kandungan penelitian pekerjaan sosial cenderung turun dalam empat hal berikut (Reid, 1995; Tripodi \& Lalayants, 2008). Pertama, banyak studi melibatkan perilaku individu klien dan interaksi mereka dengan orang lain dekat dengan

mereka, termasuk keluarga dan kelompokkelompok kecil. kedua, banyak penelitian berfokus pada bagaimana layanan disediakan untuk klien, layanan apa yang terlibat, dan hasil mereka dalam mencapai tujuan. Ketiga, beberapa studi mengatasi sikap pekerja sosial 'dan latar belakang pendidikan, di samping tren utama dalam profesi. Keempat, beberapa penelitian melibatkan studi tentang "organisasi, masyarakat, dan kebijakan sosial" (Reid, 1995, hlm. 2044). Kategori terakhir menekankan pentingnya lingkungan sosial yang lebih besar dan dampaknya pada perilaku dan

kondisi klien.

g. Kompetensi 7: Penerapan Pengetahuan Perilaku Manusia dan Lingkungan Sosial

Pekerja sosial harus berpengetahuan tentang perilaku manusia dan lingkungan sosial. Fungsi masyarakat dalam konteks lingkungan merupakan dorongan penting dari pekerjaan sosial. Hanya setelah menilai dan pemahaman bahwa fungsi dapat pekerja sosial melanjutkan dengan

rencana intervensi. Para pekerja sosial harus memiliki pengetahuan tentang "biologis, sosial, budaya, psikologis, dan pengembangan spiritual "karena hal ini terjadi atas umur (CSWE, 2008b, hal. 6). "Perilaku Manusia dan Lingkungan Sosial "adalah dasar untuk kursus lain atau urutan program tradisional dimasukkan dalam kurikulum pekerjaan sosial. Orang-orang terus-menerus dan dinamis terlibat dalam kegiatan yang sedang berlangsung dan komunikasi dengan orang lain

di lingkungan. Penilaian adalah identifikasi dari "sifat dan tingkat kebutuhan klien dan keprihatinan, 
serta informasi penting tentang sumber daya klien

dan mendukung dan faktor lingkungan lainnya "sehingga rencana untuk membantu dapat dirancang dan dilaksanakan (Blythe \& Reithoffer, 2000, hal. 551).

Assesment pekerja sosial dilakukan untuk menemukan situasi tertentu apa yang menyebabkan masalah untuk melanjutkan perubahan yang diinginkan klien. Berfokus pada lingkungan berarti tidak hanya melihat pada individu itu sendiri tetapi juga pada keterlibatan mereka dengan anggota keluarga, tetangga, pekerjaan kolega, sistem politik, dan lembaga layanan di dalam masyarakat. Berarti bahwa masalah-masalah klien tidak melihat semata-mata sebagai kesalahan milik mereka.

Kemiskinan, diskriminasi, tekanan sosial, dan efek dari kebijakan kesejahteraan sosial, semua aspek kehidupan masyarakat yang dapat jatuh di bawah pengawasan.

h. Kompetensi 8: Keterlibatan dalam Praktek Kebijakan untuk Memajukan

Perekonomian dan Kesejahteraan Sosial

Para pekerja sosial harus memahami kebijakan sosial, kesejahteraan, sejarah mereka, dan bagaimana pengaruh pekerjaan terhadap klien.

Kebijakan, dalam bentuk yang paling sederhana,

dapat dianggap sebagai aturan. Hidup kita dan orang-orang dari klien pekerja sosial diatur oleh aturan-tentang bagaimana kita berkendara, ketika kita pergi ke sekolah, bagaimana kita berbicara atau menulis kalimat, dan sebagainya.

Kebijakan, pada dasarnya, aturan yang memberitahu kita tindakan antara tindakan kita yang dapat dilakukan dan yang tidak. Kebijakan memandu pekerjaan dan keputusan. Untuk tujuan pemahaman kesejahteraan sosial dan penyediaan kesejahteraan sosial jasa, kebijakan mungkin dibagi menjadi dua kategori utama: kebijakan kesejahteraan sosial dan kebijakan lembaga. Kebijakan kesejahteraan sosial adalah hukum dan peraturan yang mengatur program kesejahteraan sosial mana yang ada, kategori klien apa yang dilayani, dan siapa yang memenuhi syarat untuk program yang diberikan. Mereka juga menetapkan standar tentang jenis layanan yang akan diberikan dan kualifikasi dari penyedia layanan. Selain ranah yang lebih luas kebijakan kesejahteraan sosial, kebijakan lembaga yang standar yang diadopsi oleh

organisasi individu dan program yang menyediakan

layanan (misalnya, sebuah lembaga pelayanan keluarga, Departemen suatu pelayanan manusia, atau panti jompo). Standar tersebut dapat menetapkan struktur badan, kualifikasi supervisor dan pekerja, aturan yang mengatur apa yang dapat dilakukan pekerja, dan prosedur yang tepat untuk menyelesaikan penilaian keluarga. Pengetahuan tentang kebijakan sangat penting bagi pekerja sosial. Kebijakan organisasi dapat menentukan berapa banyak liburan yang dimiliki seorang karyawan dan bagaimana kenaikan gaji yang diperoleh. Kebijakan menentukan siapa yang membutuhkan pelayanan dan sumber daya.

Para pekerja sosial harus turut berperan aktif dalam membangun dan perubahan kebijakan kesejahteraan sosial bagi kepentingan klien mereka; Kebijakan menentukan bagaimana uang dianggarkan dan dihabiskan, dan di mana sumber

yang dibuat tersedia untuk klien. Praktisi harus

kompeten dalam melakukan praktek kebijakan untuk meningkatkan kesejahteraan dan memberikan layanan pekerjaan sosial yang efektif bagi masyarakat. Praktek kebijakan melibatkan "upaya untuk mengubah kebijakan, pengaturan lembaga, dan komunitas legislatif, apakah dengan menetapkan kebijakan baru, meningkatkan yang sudah ada, atau mengalahkan inisiatif kebijakan

orang lain" (Jansson, 2011, hal. 15).

Kadang-kadang, kebijakan kesejahteraan sosial tidak adil atau menindas kepada klien. Ironisnya, meskipun kebijakan tersebut dimaksudkan untuk meningkatkan kesejahteraan rakyat, kadang-kadang malah 
sebaliknya. Pekerja sosial dapat memutuskan bahwa kebijakan yang etis dan mengadvokasi atas nama klien, mencoba untuk mengubahnya. Praktisi dapat bekerja untuk mengubah kebijakan untuk memajukan keadilan sosial dan ekonomi dan memberikan perlakuan yang adil terhadap berbagai orang.

i. Kompetensi 9: Responsif terhadap Konteks dari Bentuk Praktik

Para pekerja sosial harus menunjukkan kompetensi dalam berbagai konteks dan pengaturan. Mereka harus memahami dinamika dan terlibat dalam lingkungan makro seperti organisasi, masyarakat, dan badan legislatif yang menetapkan kebijakan kesejahteraan sosial. Praktisi harus berfungsi dalam sistem, melayani sebagai pemimpin untuk mengadvokasi atas nama klien. Mereka harus mengikuti perkembangan teknologi baru, perubahan demografi, dan tren sosial dalam rangka untuk menanggapi isu-isu saat ini.

j. Kompetensi 10: Perjanjian, Assessment, Intervensi, dan Evaluasi dengan Individu, Keluarga, Kelompok Besar, Organisasi, dan Komunitas

Ada dua dimensi utama yang melekat dalam Kompetensi 10. Pertama, proses pekerjaan sosial meliputi keterlibatan, penilaian, intervensi, dan evaluasi (CSWE, 2008b; Kirst-Ashman \& Hull, 2012b). Keterlibatan/perjanjian adalah periode awal ketika praktisi mengorientasikan diri untuk masalah yang dihadapi dan mulai menjalin komunikasi dan hubungan dengan lain juga mengatasi masalah. Assessment melibatkan penyelidikan dan penentuan variabel yang mempengaruhi identifikasi masalah termasuk kebutuhan dan kekuatan klien. Intervensi adalah perencanaan dan pelaksanaan rencana untuk memecahkan masalah dan mencapai tujuan. Evaluasi adalah "proses penentuan apakah perubahan yang terjadi bermanfaat." (Kirst-Ashman \& Hull, 2012a, hal. 34). Keterampilan lain yang terlibat dalam praktek pekerja sosial meliputi "memberikan kepemimpinan untuk kebijakan dan jasa serta mempromosikan keadilan sosial dan ekonomi" (CSWE, 2008b, hal. 7). Dimensi penting kedua yang melekat dalam kompetensi 10 adalah bahwa praktek melibatkan bekerja dengan individu, keluarga, kelompok, organisasi (besar dan kecil), dan masyarakat.

keterampilan

Basis pengetahuan pekerjaan sosial mencakup informasi tentang keterampilan di samping data mengenai masalah dan layanan. seorang pekerja sosial harus tahu keterampilan apa yang paling efektif dalam situasi seperti apa, keterampilan-keterampilan untuk mencari dan menghubungkan orangorang dengan sumber daya yang mereka butuhkan. Para pekerja sosial dapat memilih dari banyak teknik praktek dan teori. Pengetahuan tentang efektivitas berbagai teknik sangat penting untuk memilih orangorang yang dapat mencapainya dalam situasi tertentu dan untuk melaksanakan praktek research-information (kompetensi 6). Terlepas dari teknik yang dipilih dan digunakan, penekanan ditempatkan pada kekuatan klien dan pemberdayaan, kolaborasi klien yang sedang berlangsung di semua tahap proses perubahan, dan penghargaan keanekaragaman (Pinderhughes, 1995). Landasan praktek pekerja sosial adalah praktek generalis.

\section{Praktek Generalis}

Praktek generalis menggabungkan semua 10 kompetensi dan merupakan inti dari pendidikan dan praktek pekerjaan sosial. Ini membedakan pekerjaan sosial dari profesi lain. Praktek generalis adalah aplikasi dari basis pengetahuan eklektik, nilai-nilai profesional, dan berbagai keterampilan untuk menargetkan berbagai ukuran sistem untuk perubahan dalam konteks empat primer proses (Kirst-Ashman \& Hull, 2012b). Pertama, generalis

praktek menekankan pemberdayaan klien. Kedua, melibatkan bekerja secara efektif dalam sebuah struktur organisasi dan melakukannya di bawah pengawasan. Ketiga, memerlukan asumsi lebar berbagai peran 
profesional. Keempat, melibatkan aplikasi keterampilan berpikir kritis untuk perencanaan proses perubahan (intervensi).

\section{Advanced Practice}

Mencirikan kurikulum MSW, memberikan konsentrasi khusus yang dibangun berdasarkan landasan praktek generalis. Misalnya, spesialisasi dalam kesehatan mental, pekerja sosial sekolah, bekerja dengan anak-anak dan keluarga, koreksi, kesehatan, pelayanan sosial administrasi, atau organisasi masyarakat.

\section{Bidang Pendidikan}

Merupakan bentuk pusat instruksi dan pembelajaran di mana sosialisasi profesi untuk melakukan peran praktisi" (CSWE, 2008b, hal. 8). Bidang pendidikan menyediakan pengalaman kehidupan nyata dalam lingkungan kerja sosial di mana pekerja sosial ditempatkan dan dapat berlatih keterampilan mereka di bawah pengawasan. Pengaturan penempatan dapat bervariasi. Mereka termasuk lembaga pelayanan sosial, rumah sakit, sekolah, lembaga pemasyarakatan, organisasi penempatan seperti kantor cabang NASW negara,

penempatan yang berkaitan dengan kebijakan seperti kantor legislatif, atau penempatan dalam organisasi masyarakat. Setiap dari pengaturan ini harus menyediakan pengawasan kerja sosial yang sesuai. Penempatan BSW memerlukan minimal 400 jam dan MSW penempatan minimum 900 jam. Banyak siswa pekerjaan sosial menemukan

pendidikan bidang mereka untuk menjadi titik pengalaman pendidikan mereka.

Konsep penting dalam sistem teori dan ekologi merupakan perspektif yang relevan dengan praktek kerja sosial termasuk sistem (mikro, mezzo, dan makro), sistem klien, lingkungan sosial, dan coping.

\section{PENUTUP}

Pekerjaan sosial adalah kegiatan profesional membantu individu, kelompok, atau masyarakat meningkatkan atau memulihkan kapasitas mereka untuk berfungsi sosial dan menciptakan kondisi sosial yang menguntungkan. Bidang praktek dalam pekerjaan sosial termasuk anak-anak dan keluarga, lansia, difable, kesehatan, kesehatan mental, penyalahgunaan zat, sekolah, dan koreksi. Konteks lain untuk praktek pekerjaan sosial adalah pekerjaan sosial pedesaan, polisi pekerjaan sosial, dan pekerjaan sosial forensik.

Pekerjaan sosial dibangun di atas berbagai disiplin ilmu, termasuk psikologi, sosiologi, ilmu politik, ekonomi, biologi, psikiatri, konseling, dan antropologi. Pekerjaan sosial adalah unik karena berfokus pada masalah orang-orang yang paling sulit, sering menargetkan lingkungan untuk perubahan, menekankan perlunya advokasi klien, berdasarkan pada inti profesionalitas seperti nilai-nilai, dan menekankan pentingnya kerja dalam kemitraan dengan klien.

Pengembangan diri, penguasaan teknologi pekerjaan sosial dan kiprah yang lebih profesional merupakan hal yang krusial yang harus segera dilakukan untuk menjawab tantangan-tantangan yang dihadapi oleh pekerja sosial, sehingga pekerjaan sosial bisa diakui keberadaanya oleh masyarakat secara luas, dan juga oleh profesi lainnya sebagai sebuah profesi yang profesional, bukan lagi kegiatan amal/karitas lagi. Setidaknya ada sepuluh kompetensi yang harus dimiliki oleh pekerja sosial dalm prakteknya.

Adapun dalam "IUC Journal of Social Work: Theory and Practice" disebutkan mengenai lima praktek pekerja sosial. Pertama, pekerja sosial membantu individu, kelompok, atau komunitas. Para pekerja sosial memberikan konseling bila diperlukan untuk membantu klien mengatasi masalah. Selain konseling individu atau keluarga, banyak pekerjaan sosial melibatkan bekerja sama dengan organisasi dan masyarakat untuk 
meningkatkan kesehatan dan layanan sosial. Kedua, pekerjaan sosial memerlukan dasar yang kuat; nilai-nilai dan prinsip-prinsip yang memandu praktisi apa harus dan tidak boleh dilakukan. Ketiga, dasar yang kuat mengenai teknik dan keterampilan memberikan petunjuk bagaimana pekerja sosial harus memberikan treatment dan mencapai tujuan. Keempat, pekerja sosial membantu orang mendapatkan layanan yang mereka butuhkan dengan menghubungkan mereka dengan sumber daya yang tersedia. Jika sumber daya yang tepat tidak tersedia, pekerja sosial dapat melakukan advokasi untuk pengembangan layanan atas nama klien mereka. Kelima, pekerja sosial berpartisipasi dalam proses legislatif untuk mempromosikan perubahan sosial positif. Para pekerja sosial juga dapat berfungsi sebagai saksi/ahli untuk mendidik legislator tentang masalah dan kebutuhan klien, berbagi pendapat, bertanggung jawab secara sosial, dan menjalankannya.

Wilfried Ferchhoff mengembangkan tiga jenis identitas (tiga konsep) profesionalisme yang dipengaruhi oleh proses sejarah identitas pekerja sosial, yang terdiri dari pekerja sosial sebagai pribadi altruistik (produk dari waktu Alice Salomon, 1872 sampai 1930); sosial engineer; dan pekerja sosial sebagai hermeneutik-people. Saran dari Uhlendorff Ferchhoff lebih menyukai jenis ketiga yaitu pekerja sosial sebagai pribadi hermeneutik. Uhlendorff menyarankan memanfaatkan untuk jenis identitas, diagnosis sosial hermeneutik dalam proses bantuan. Di satu sisi Uhlendorff menyatakan bahwa diagnosis mencegah kerjasama antara klien dan orang yang profesional. Pekerja sosial dan klien bekerja sama sebagai sebuah tim. Mereka mengamati dan menafsirkan biografi, situasi konflik dan lingkungan klien.

\section{DAFTAR RUJUKAN}

Ashman, Karen K.Khirst. 2013. Introduction to Social Work and Social Welfare: Critical Thinking Perspective. USA: Cengage Brain.

Reid, K. 1999. Truancy and Schools.Routledge Taylor and Francis Group:New York and London.

Skidmore. Introduction to Social Work Sixth Edition. Prentice Hall International Edition.

Wibawa, Budhi, et al. 2010. Dasar-dasar Pekerjaan Sosial. Widya Padjadjaran:Bandung.

\section{Sumber Jurnal/Artikel}

Azril. 2014. Eksistensi Pekerja Sosial Diperkuat Akreditasi. Tribun, 3 Oktober 2014.

Badiklitkesos. 2013. Sejarah Baru Perkembangan Pekerja Sosial di Indonesia. Jakarta: OHH.

Hare, Isadora. 2009. Defining Social Work: The International Federation of Social Worker. London: Sage Publications. 47 (3), 7-14.

Jung, Barbara. 2007. Social Worker Identity Between Critical and Rational Understanding. IUC Journal of Social Work: Theory and Practice.

Martin, etc. 2009. Multidiciplinary Team Working: From Theory to Pactice. Discussion paper MHC. Waterloo Dublin 4.

P4S Kemsos. 2014. Standar Registrasi, Akreditasi, dan Sertifikasi Pekerja Sosial. Jakarta: Kementerian Sosial RI.

Widgren, Erja. 2013. Social Work in a MultiProfessional Environment. IUC Journal of Social Work: Theory and Practice. 
http://www.microsite.metrotvnews.com/metro news/read/2014/09/02/3/185591/

\section{Sumber Lainnya}

http://www.dpr.go.id/id/berita/komisi8/2014/f eb/04/7538/perlu-standarisasi-

kompetensi- pekerja-sosial diakses pada 1 Oktober 2014 pukul 15.05 WIB. http://www.iassw.aiets.org diakses pada 1 Oktober 2014 pukul 14.48 WIB. diakses pada 1 Oktober 2014 pukul 14.07 WIB. 